\section{Some observations on vultures in Pench Tiger Reserve, Madhya Pradesh}

\section{Aniruddha Majumder ${ }^{1}$, Santanu Basu ${ }^{1}$, K. Sankar ${ }^{2}$ \& Qamar Quresh ${ }^{1}$}

1,2 Wildlife Institute of India, Chandrabani, P.O. Box \# 18, Dehra Dun, Uttarakhand 248001, India

Email: ${ }^{2}$ sankark@wii.gov.in (corresponding author)

Between October 2006 and June 2008 information on population, group size, habitat use and food habits of six species of vultures was collected in Pench Tiger Reserve $\left(79^{\circ} 9^{\prime}-79^{\circ} 22^{\prime}\right.$ $\left.30^{\prime \prime} \mathrm{E} \& 21^{\circ} 38^{\prime}-21^{\circ} 50^{\prime} 30^{\prime \prime} \mathrm{N}\right)$ Madhya Pradesh. The Tiger Reserve comprises of Sanctuary, National Park and reserved forests. The total area of the Pench Tiger Reserve is $758 \mathrm{~km}^{2}$. According to Champion \& Seth (1968) the flora of Pench falls under tropical dry deciduous forest (Champion \& Seth 1968). Based on ad-libitum observations, locations of vultures were recorded using Global Positioning System (GPS) from the entire Tiger Reserve. In addition, the number of individuals of each species, major vegetation type around $20 \mathrm{~m}$ radius and the prey species on which vultures were found feeding were also noted on each observation.

In total 547 individuals belonging to six species of vultures were recorded. Of these, the Oriental White-backed or Whiterumped Vulture (Gyps bengalensis) were found to be the most abundant $(\mathrm{n}=334)$ followed by Long-billed Vulture (Gyps indicus) $(\mathrm{n}=184)$, Red-headed or King Vulture (Sarcogyps calvus) $(\mathrm{n}=12)$, Egyptian Vulture (Neophron percnopterus) $(\mathrm{n}=9)$, Indian Griffon Vulture (Gyps fulvus) $(\mathrm{n}=5)$ and Cinereous Vulture (Agypius monachus) $(\mathrm{n}=3)$. The Indian Griffon and Cinereous Vulture were recorded only during winter (NovemberFebruary) whereas the other four species were recorded throughout the year.

The number of individuals and percentage flock size of vultures is given in Table 1. A maximum of 28 individuals were recorded for white-backed vulture in a flock, where as the

Date of publication (online): 26 December 2009

Date of publication (print): 26 December 2009

ISSN 0974-7907 (online) | 0974-7893 (print)

Editor: J. Praveen

Manuscript details:

Ms \# 02202

Received 08 May 2009

Final received 08 October 2009

Finally accepted 01 December 2009

Citation: Majumder, A., S. Basu, K. Sankar \& Q. Quresh (2009). Some observations on vultures in Pench Tiger Reserve, Madhya Pradesh. Journal of Threatened Taxa 1(12): 627-628.

Copyright: @ Aniruddha Majumder, Santanu Basu, K. Sankar \& Qamar Quresh 2009. Creative Commons Attribution 3.0 Unported License. JoTT allows unrestricted use of this article in any medium for non-profit purposes, reproduction and distribution by providing adequate credit to the authors and the source of publication.

Acknowledgments: We would like to thank Madhya Pradesh Forest Department for granting permission to work in Pench for the research project 'Ecology of tigers', the Director and Dean of Wildlife Institute of India (WII) for their support and encouragement extended during the field work.

OPEN AGGESS | FREE DOWNLOAD

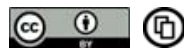

Long-billed Vulture had a maximum of 18 individuals in a flock. Multiple associations among different species of vultures were also recorded during study period (Table 2).

Vultures were largely found in riparian forest $(70 \%)$ followed by miscellaneous forest (23\%) and teak mixed forest (7\%). White-backed and Long-billed Vulture nests were recorded on Tectona grandis and Dalbergia paniculata at four sites each in Gumtara, Alikatta, Chiklakhari and Chindwani. No attempts were made to study the nesting success of vultures. However fledglings of White-rumped Vultures were seen once during the study period.

In total 24 kills of Wild Ungulates (20 Chital, three Sambar and one Nilgai) were recorded. Of these, 16 kills were located due to vulture's activity. On ten occasions Jungle Crow (Corvus macrorhynchos) was found associated with vultures on the feeding grounds followed by Golden Jackal (Canis aureus) on five occasions and Wild Pig (Sus scrofa) on two occasions. During the study period two vultures, one each of White-backed and Long-billed were found dead in the study area. Post-mortem reports revealed that these were natural deaths (Akhilesh Mishra pers. com.). Since Pench harbours one of the highest prey-predator densities (Biswas \& Sankar 2002) in central Indian landscape, vultures have better chance of survival on carnivore kills. It is suggested that the reported breeding sites of vultures in Pench need monitoring for the survival of chicks. Since the 1990s vulture populations especially the Gyps species across the Indian subcontinent have declined drastically (Gilbert et al. 2002; Prakash et al. 2003; Green et al. 2004). The findings of the present study showed encouraging results regarding the population of Gyps species in Pench

\section{References}

Biswas, S. \& K. Sankar (2002). Prey abundance and food habits of tigers (Panthera tigris) in Pench National Park, Madhya Pradesh. Journal Zoology, London 256: 411-420.

Champion, H.G. \& S.K. Seth (1968). A Revised Survey of the Forest Types of India. Manager of publications, Govt.of India Press, New Delhi, $404 \mathrm{pp}$

Gilbert, M., M.Z. Virani, R.T. Watson, J.L. Oaks, P.C. Benson, A.A. Khan, S. Ahmed, J. Chaudhry, M.S. Mahmood \& Q.A. Shah (2002). Breeding and mortality of oriental White-backed Vulture Gyps bengalensis in Punjab Province, Pakistan. Bird Conservation International 12: 311-326.

Green, R.E., I., Newton, S. Shultz, A.A. Cunningham, M. Gilbert, D.J. Pain \& V. Pakash (2004). Diclofenac poisoning as a cause of vulture population declines across the Indian subcontinent. Journal Applied Ecology 41: 793-800.

Prakash, V., D.J. Pain, A.A. Cunningham, P.F. Donald, N. Prakash, A. Verma, R. Gargi, S. Sivakumar \& A.R. Rahmani (2003). Catastrophic collapse of Indian white-backed (Gyps bengalensis) and Long-billed (Gyps indicus) Vulture populations. Biological Conservation 109: $381-390$ 
Table 1. Number of individuals and percentage flock size recorded for six species of vultures in Pench Tiger Reserve (2006-2008)

\begin{tabular}{|c|c|c|c|c|c|c|c|c|}
\hline \multirow[t]{2}{*}{ Species } & \multirow{2}{*}{$\begin{array}{l}\text { Number } \\
\text { of flocks }\end{array}$} & \multirow{2}{*}{$\begin{array}{l}\text { Mean } \\
\text { flock size }\end{array}$} & \multirow{2}{*}{$\begin{array}{l}\text { Number } \\
\text { of individuals }\end{array}$} & \multicolumn{5}{|c|}{ Flock size in $\%$} \\
\hline & & & & 1 & $2-3$ & $4-10$ & $11-20$ & $21-30$ \\
\hline King vulture & 11 & 1.5 & 12 & 91 & 9 & - & - & - \\
\hline White-backed vulture & 66 & 14 & 334 & 11 & 50 & 26 & 11 & 3 \\
\hline Long-billed vulture & 37 & 9 & 184 & 24 & 27 & 37 & 11 & - \\
\hline Eqyptian vulture & 4 & 1.5 & 09 & 50 & 50 & - & - & - \\
\hline Indian griffon vulture & 3 & 1.5 & 05 & 33 & 66 & - & - & - \\
\hline Cinereous vulture & 1 & 3 & 03 & - & 100 & - & - & - \\
\hline
\end{tabular}

Table 2. Multiple associations among different species of vultures recorded in Pench Tiger Reserve (2006-2008)

\begin{tabular}{ll}
\hline Species associations & Number of occasions \\
\hline Long billed - White Backed & 15 \\
White backed - Long billed - Egyptian & 3 \\
White backed - King Vulture & 2 \\
King Vulture - White backed - Long billed & 3 \\
King Vulture - White backed - Long billed - Egyptian - Indian Griffon & 1 \\
King Vulture - White backed - Long billed - Egyptian - Indian Griffon - Cinereous & 1 \\
\hline
\end{tabular}

